Nowoczesne Systemy Zarządzania

Zeszyt 13 (2018), nr 3 (lipiec-wrzesień)

ISSN 1896-9380, s. 235-244

Modern Management Systems

Volume 13 (2018), No. 3 (July-September)

ISSN 1896-9380, pp. 235-244
Instytut Organizacji i Zarządzania

Wydział Cybernetyki

Wojskowa Akademia Techniczna

w Warszawie

Institute of Organization and Management

Faculty of Cybernetics

Military University of Technology

\title{
Value Creation: The Internal Perspective
}

\section{Kreowanie wartości w organizacji: perspektywa wewnętrzna}

\author{
Diana Teixeira \\ School of Management and Technology \\ Porto Polytechnic Institute, Center for Research and Innovation \\ in Business Sciences and Information Systems - CIICESI \\ Nelson Duarte \\ School of Management and Technology \\ Porto Polytechnic Institute, Center for Research and Innovation \\ in Business Sciences and Information Systems - CIICESI
}

\begin{abstract}
The present research aims to approach leadership techniques in order to analyze whether those techniques promote and stimulate value creation and co-creation. The main goals were the identification of value creation's main sources in the footwear sector. This research was applied in a Portuguese region (Tâmega e Sousa) in the north of Portugal. In order to collect empirical data, the main focus was the learning and growth perspective, connected to the trinomial internal leadership, human capital's valorization and added value's creation. For the empirical research, a quantitative method was used in order to answer the main goal: In what way the ability to lead internal stakeholders promote value creation in the footwear industry? The data collection was achieved through a questionnaire applied, in person and via email, to industrial leaders and their employees. In an analysis to Tâmega e Sousa Region's footwear industry, it was concluded that there is a clear focus in internal processes, customer retention and satisfaction as well as a transversal financial concern. However there is a low investment in the learning and growth perspective. That means, there's a need to invest and/or develop motivational, performance and knowledge management processes and to define policies for recognition, relationship valorization and competence development. Keywords: leadership, value, knowledge, satisfaction, valorization.
\end{abstract}

Abstrakt: Celem artykułu jest zaprezentowanie koncepcji przywództwa wraz ze stymulantami kreowania i współkreowania jego wartości w postaci zasobów w przemyśle obuwniczym. Badanie zostało przeprowadzone w regionie Tâmega e Sousa w północnej Portugalii. W celu zebrania danych empirycznych podjęto studia literaturowe, oparte na trójmianie przywództwa, waloryzacji zasobów ludzkich oraz tworzeniu 
wartości dodanej. W artykule sformułowano następujący problem badawczy: w jaki sposób zdolność do przewodzenia wewnętrznymi interesariuszami pomaga kreować wartości w przemyśle obuwniczym? Aby osiągnąć odpowiedź na powyższy problem, zastosowano badanie ilościowe w formie ankiety bezpośredniej i internetowej. Grupę badawczą stanowiła kadra zarządzająca i pracownicy firm sektora obuwniczego. Wyniki badania pokazały, że najczęstszymi problemami tych firm są kwestie wewnętrzne: utrzymanie pracowników i utrzymanie ich satysfakcji oraz kwestie finansowe. Przy wysokim udziale tych czynników, inwestycje w uczenie się i rozwój nie odgrywają znacznej roli. Widać więc, że istnieje potrzeba inwestowania w rozwój i motywację pracowników, ich wydajność i zarządzanie wiedzą. Jednocześnie nie należy zapominać o uznaniowości, waloryzacji relacji i rozwoju kompetencji.

Słowa kluczowe: przywództwo, wartość, satysfakcja, waloryzacja.

\section{Introduction}

Project Based Firms, according to the PMBOK ${ }^{\oplus}$ Guide (PMI, 2017), are companies that organize themselves according to projects. These organizations focus on the innovative projects' design, development and delivery. This should be an integrative process, aligning a broad vision and diverse knowledge such as management, communication and human resources (HR). These areas are fundamental to delegate tasks, manage people and their competencies, and ensure information and control's adequate flow. One of the great value creation stimulators is innovation, and HR are the key figure in innovation (De Silva, Howells, \& Meyer, 2018). Attached to the concept of HR is the concept of Leadership, since the latter is the key to keep people in organizations - HR - motivated.

In order to describe Leadership there's a focus on creativity, satisfaction and communication effectiveness, team development and learning capacity (Avolio, Walumbwa, \& Weber, 2009; Solansky, 2008). Therefore, the leadership model must be transformed from the concept of leader into that of facilitator; a creator and guardian of a safe environment for creation and active participation (Reed, 2006). The Leadership style varies according to the context. Leading in services, is considerably different from leading in manufacturing, which has a hierarchical organizational structure, against the typical matrix presented in the services sector (Avolio et al., 2009).

Hence the challenge of the in-depth study of leadership typically in manufacturing regions, where most leaders accumulate the role of managers, innovators, consultants and commercials seems to be relevant.

With the present paper it is intended to identify the differences and similarities between leaders and teams (employees/subordinates) on what regards value creation. In other words, how and what do these groups identify as important value creators within a company. In order to develop this research the footwear industry in Tâmega e Sousa Region was chosen. This industry assumes knowledge and innovation as its structuring values. Therefore, the industry main challenges' are to attract, train and retain qualified resources for firms' functional domains. At the same time, this industry is seeking for competitive advantages based on products, processes and business models innovations. 
Bearing in mind this scenario, the present research intents to explore a seemingly reserved sector in terms of information sharing - the footwear industry. It is quite common to find a Taylorist management model, in terms of methods and procedures. However, this trend has been changing and industries are increasingly concerned with the propelling role of stakeholders and their ability to influence the capture, generation, creation of value (Apiccaps, 2013). For that the paper will start by a brief review of the state of art, followed by the research methodology and region presentation. After that it will be presented the discussion of the main topics and the paper conclusions.

\section{Theoretical Background}

It's not always clear how companies manage and optimize their HR skills. But, it's evident that any integrated value creation strategy should, not only, pass by optimization of internal processes, retention, attraction and customer satisfaction, and turnover maximization, but also, and above all, by investment and optimization of learning and knowledge (Norrie \& Walker, 2004). Managers and organizations agree that one of the success factors of their organizations is the effectiveness of communication processes and methods (Neves \& Eisenberger, 2012)and its consequences for performance. We assessed management communication and POS 2 times, separated by a 3-year interval, in a social services organization $(\mathrm{N}=236$. If communication channels are reliable and strategies are effective, together with a close relationship between leaders and teams is a value creation source (Miller, 2015). This is also verified when it comes to external stakeholders relationships (Balkundi et al., 2016; Zander, Mockaitis, \& Butler, 2012).

According to P. Aghion and J. Tirole (Aghion, Tirole, 1997), formal hierarchical authority has limitations. The manager effectiveness depends further on skills than on authority. So, leading means achieving results through the mobilization of people, considering factors such as motivation, the project's mission, manager's capacities and the context where the process occurs (Miles, Van Clieaf, 2017; Müller, Turner, 2010).

Responsible leadership can result in the creation of multi-stakeholder value networks (Goleman, 2012), which increase social capital and thus contribute as much to a sustainable business as to the common good (Sharma, Smith, 2002). T. Maak (Maak, 2007) refers that value creation results from the valorization of social capital, through the development of structural, cognitive and relational aspects. The leader and team commitment towards to the organization, the skills valorization and development, motivational management and stakeholder involvement also play an important role. 
Kazadi, Lievens \& Mahr (Kazadi, Lievens, Mahr, 2015) affirm that value creation is a process by which the organization (1) attracts, acquires and accumulates unique and valuable talent resources and exploits its potential to create value, (2) organize its talent resources with other resources to enhance synergies, (3) develops and expands the inherent capabilities of their talent resources to add new value to them, and (4) develops isolation mechanisms to prevent their retain their talented resources.

This perspective is presented as a new value theory that "places emphasis on improving organizational and economic performance, enhancing value creation capacity" (Miller, 2015). The simple value capturing (emphasis on maximizing profits) was replaced by a new principle that proposed to co-create (value) through processes that required relationships and communication with stakeholders in order to identify results that maximize the benefits for all in the company (De Silva et al., 2018).

This value creation new principle is focused on knowledge, relationships, stakeholders and social capital. All of these (value) assets are key intangible factors to generate the type of innovation needed to improve organizational and economic performance (Miles, Van Clieaf, 2017). However the perception of value by each stakeholder is distinct and complementary, since aspirations and joint resources are needed (Porter, Kramer, 2011).

Most companies are now in a process of transition that aims to revolutionize their methods of leadership and motivational management, distancing them (in the industry's case) from a purely internal perspective to an approach that embraces the relationships' valorization, knowledge capital and assets' recognition (stakeholders). An effective transition from the Creation to the Value Co-creation perspective is expected (Pera, Occhiocupo, Clarke, 2016).

Today, value creation has a significantly higher basis of intangibility, which brings us even more challenging elements for the paradigm change from the vision of financial capital only to others capitals (recognized but not quantified) such as the intellectual, human, natural and social (Miles, Van Clieaf, 2017). Value co-creation, so desired by employees and customers, is essentially focused on interaction (De Silva et al., 2018). While in value creation, stakeholders receive value from the company's activity, in co-creation they participate in value creation through personal involvement (Payne, Storbacka, Frow, 2008). Co-creation extends value creation as a paradigm in the way: (1) we proceed to value generate and construct (everyone's involvement), (2) the real nature of value (dialogue, transparency, accessibility, experiences) is framed and (3) the virtual source of value is deepened (emerging values of ecosystems of inclusive, generating, linking and evolutionary potentialities) (Roser, 2014).

Therefore, according to Kazadi et al. (Kazadi, Lievens, Mahr, 2015) co-creation requires a change in the company's thinking regarding the stakeholders' involvement 
(individually and collectively) as well as an expansion on the way companies articulate value creation opportunities with resources. It also requires a formulation of purposefully designed engagement in order to gather people, processes, interfaces, and artifacts that provide interaction environments to enhance co-creation actions and generate mutually valuable results. Co-creation is the union of value creation and developed with stakeholders.

The value creation process begins from inside. The isolated elements do not create value. They are part of the result and integrate a complex process that has and must begin in Participatory Management (Kearney, Hays, 2016).

\section{Research Metodology}

In order to answer the research question: What are the factors that leaders and employees identify as important in the value creation process? The following research objectives were defined:

- Identification of value creation sources;

- Identification of a possible relation between internal leadership, human capital valorization and value creation;

- Identification of stakeholders' importance in industrial dynamization and competitive advantage creation.

In this context, a semi-structured questionnaire was applied to the employees and leaders of footwear firms based in the region of Tâmega e Sousa.

In order to determine the population, it was used the SABI (Iberian Balance Analysis System). This system is a business database that provides legal accounting information for firms operating in Portugal and Spain. The data collected was statistically analyzed through SPSS (Statistical Package for the Social Sciences). From this database it was possible to identify 504 firms in the region. In order to perform this research both leaders and employees were questioned, the sample was composed of 52 leaders from 52 different companies and 71 employees from those 52 companies.

The questions were aligned in both questionnaires, although they have been adapted to the different categories of respondents. The results from statistical analysis allowed to draw some conclusions in order to answer the research objectives. The questionnaire was applied both face-to-face, and sent by e-mail.

The region is made up of 11 concelhos (administrative units divided into small units called freguesias). It has an area of 1,830 and a population of 434,165 inhabitants. One particular city (Felgueiras) assumes a key importance, because a footwear cluster is identified. 


\section{Analysis and Results Discussion}

From the data collected it was possible to verify that among footwear companies' leaders, $73.1 \%$ recognize the importance of investing, $67.5 \%$ identify a need to develop skills, and $69.2 \%$ a motivational need. On what comes to rewards, $53.8 \%$ identify it as an important policy. However, it seems that they are not able to communicate these concerns, neither acting accordingly. From the HR perspective, the employees' valorization it's not very noticeable (56.3\%). They also point out a low investment in training (54.9\%), and no attention from leaders to HR's interests and needs (50.7\%).

Today's leaders must have a dynamic and ethical profile as well as a capacity to integrate knowledge and foster innovation. However, HR even identifying a policy od goals setting and communication (66.2\%), as well as a problem solving approach (60.6\%) also identify a kind of persecution policy on what concerns a liability clearance in order to adopt punishment measures towards low performance's employees (78.9\%). This results, lead to a leadership style that approaches autocracy. The leaders' large majority set guidelines, with little or no participation by the group and determines the measures and techniques for the execution of the tasks.

Leadership is essentially a social process defined through interaction. Leaders have greater potential to disseminate and reinforce aspects of organizational culture if they communicate. And it is in the communication that, there is much to be done, since $47.9 \%$ of HR identified a lack of communication, along with a lack on teams' skills development (46.5\%). On what regards carreers, $56.3 \%$ of HR identified a short investment on training and motivation policies (49.3\%). In accordance to the Situational Leadership, employees want to be oriented and not supervised. Yet, $39.4 \%$ claim to be supervised, that is in accordance to the autocratic leadership style previously identified. The results tend to identify an organizational Taylor approach, rather than a democratic or transformational leadership style.

On what regards value creation, leaders and employees also present different perspectives. For 19.1\%) of leaders creating value means needs satisfaction of everyone within the company - that employees pointed as something that leaders are not performing. $18.2 \%$ believe that value creation occurs when good working conditions exist. And there is obviously the profit maximizing (17.1\%). According to $16.2 \%$ of employees, the work teams' motivation is the key to increasing productivity, which comes from commitment and voluntary involvement, and is one of the main value creation's stimulators.

So, what about the tools for the human capital valorization? According to the leaders, this valorization is mainly done through Performance Evaluation Strategies (98.1\%). However this strategies are identified by just $76.1 \%$ of employees. The development of cultural activities was also identified as a used tool by $80.8 \%$ of leaders, but just for $59.2 \%$ of employees. In fact, the second most relevant strategy identified by employees was a Feedback Strategy (69\%) and the third one was the knowledge 
of alignment of the strategic objectives (64.8\%). Both strategies were not significant on leaders perspective. Once again it seems that communication is not very effective.

Since value creation is also attached to the concept of success it was also verified the most relevant elements for success and value creation. For $84.6 \%$ of employee, success depend on the definition of responsibility. $82.7 \%$ argue that success has a direct relation with the establishment of an environment of trust and $78.8 \%$ with an efficient policy on performance and results management. Leadership was also an identified factor for success, since $76.1 \%$ mentioned the ability to lead taking into account the stakeholders needs and focus on motivation.

This brief results presentation allows us to conclude that on employees (internal stakeholders) perspective the act of leading is (or should be) less connected to command and control and more related to empowerment.

Efficient knowledge policies will promote innovation and, consequently, value creation. This might be achieved promoting a sense of belonging among employees, leading to a greater commitment, hopefully promoting new ideas' generation (73.2\% of HR).

It is possible to create organizational value if leaders take into consideration the needs of those who are led. Besides, it is possible to move away from the Taylor perspective, to a creative leadership that focus on human knowledge, in order to foster value creation.

\section{Conclusions}

The perception of value creation is divergent between leaders and employees. Employees highlight as main enhancers the professional valorization and satisfaction factors. Leaders emphasize factors related to productivity and profitability.

On what regards the creation (of value) process in a strategic analysis (Balanced Scorecard), the customer (satisfaction and retention) and, financial perspectives (profitability, results maximization and costs minimization) stand out.

Considering the learning and growth perspective, and referring to the answers given by the employees, it's important to emphasize both the leadership capacity as well as the capacity to attract, recruit, accumulate, explore, develop and manage internal stakeholders. Quite relevant for that is the employees engagement with the organizational culture. It is also important to manage and integrate organizational with personal interests.

The leadership method is seen as very important in the value creation process according to leaders who claim to adopt a leadership style that promotes information sharing. When required to self-characterize or characterize the industrial leader they assume themselves as communicative, motivating and responsible in delegating responsibilities and monitoring results. However, aspects such as the decisions they 
make must be respected, there is no room for negotiation. Employees are not taking part in the decision-making or problem-solving processes. They are, therefore, describing a profile of autocratic leadership. On the other hand, employees argue that a policy of motivation, recognition and development rather than a delegation and control policy would be more efficient.

It is consensual that internal stakeholders assume a fundamental role in the sustainability and organizational dynamism of the industry. At the same time is crucial to achieve the company strategic objectives. To do so, employees play an important role. In order to get the team engagement, it is necessary to develop techniques and processes of performance management, motivation, skills development, professional valorization and satisfaction. However, from the employees' perspective there these policies are not being adopted. In other words, it is necessary to improve communication, motivation, valorization and recognition policies in the footwear industry in the region of Tâmega e Sousa.

Leaders highlight productivity, profitability and accountability (Financial Perspective) as critical factors to an organization success. Employees highlight, in a Perspective of Learning and Growth and Internal Processes, intangible elements such as trust, communication, motivation and interaction. The present research has led to the conclusion that there is a need of investment mainly in the qualification of its human capital and in motivation and recognition strategies.

In relation to the employees' professional valorization and satisfaction, industrial leaders state that they have as principle the dialogue, respect for employees, a policy of benefits and negotiation. Leaders also argue that they are concerned with the career management and development of their employees. However, the results from employees perspective are not in accordance.

There is little investment in professional valorization and satisfaction processes and a deficient use of the hitherto existing in the companies. More important than implementing standard processes is the identification of internal needs and the adoption of methods that increase the capacity for a value-based approach.

All organizations develop people management, technology, organizational culture and leadership. But most don't align these assets with strategy. Industry needs to be aware that depends fundamentally on its human capital to achieve the much-desired value creation.

\section{BIBLIOGRAPHY}

[1] Aghion P., Tirole J., 1997, Formal and Real Authority in Organizations. "Journal of Political Economy", 105(1), pp. 1-29.

[2] ApICCAPs, 2013, Footure 2020 Plano Estratégico - Cluster do Calçado (APICCAPS).

[3] Avolio B. J., Walumbwa F. O., Weber T. J., 2009, Leadership: Current Theories, Research, and Future Directions, "Annual review of psychology", 60, pp. 422-441. 
[4] Balkundi P., Kilduff M., Das T. K., Teng B.-S., Mumford M. D., Todd E. M., 2016, Evolution of Situational Leadership Theory: A Critical Review, "The Leadership Quarterly”, 23(3), pp. 821-830.

[5] De Silva M., Howells J., Meyer M., 2018, Innovation Intermediaries and Collaboration: Knowledge-Based Practices and Internal Value Creation, "Research Policy", 47(1), pp. 70-87.

[6] Goleman D., 2012, Inteligência Emocional: A Teoria Revolucionária, “Objetiva”, Ed., Vol. 53, Rio de Janeiro.

[7] Kazadi K., Lievens A., Mahr D., 2015, Stakeholder Co-Creation During the Innovation Process: Identifying Capabilities for Knowledge Creation Among Multiple Stakeholders, "Journal of Business Research", 69(2), pp. 525-540.

[8] Kearney R. C., Hays S. W., 2016, Labor-Management Relations and Participative Decision Making: Toward a New Paradigm, "Public Administration Review", 54(1), pp. 44-51.

[9] MAAK T., 2007, Responsible leadership, stakeholder engagement, and the emergence of social capital, "Journal of Business Ethics", 74(4), pp. 329-343.

[10] Miles S. J., Van Clieaf M., 2017, Strategic Fit: Key to Growing Enterprise Value Through Organizational Capital, "Business Horizons", 60(1), pp. 55-65.

[11] Miller L., 2015, Value Creation: The Role of Values in Improving Organizational Performance, "World Academy of Art \& Science", 1(6), pp. 55-67.

[12] Müller R., Turner R., 2010, Leadership Competency Profiles of Successful Project Managers, "International Journal of Project Management", 28(5), pp. 437-448.

[13] Neves P., Eisenberger R., 2012, Management Communication and Employee Performance: The Contribution of Perceived Organizational Support, "Human Performance 3*”, 25(5), pp. 452-464.

[14] Norrie J., Walker D. H. T., 2004, A Balanced Scorecard Approach to Project Management Leadership, "Project Management Journal", 35(4), pp. 47-56.

[15] Payne A. F., Storbacka K., Frow P., 2008, Managing the Co-creation of Value, "Journal of the Academy of Marketing Science", 36(1), pp. 83-96.

[16] Pera R., Occhiocupo N., Clarke J., 2016, Motives and Resources for Value Co-Creation in a Multi-Stakeholder Ecosystem : A Managerial Perspective, "Journal of Business Research", 69(10), pp. 4033-4041.

[17] Porter M. E., Kramer M. R., 2011, Creating Shared Value, “Harvard Business Review”, 89, pp. 62-77.

[18] PMI, 2017, A guide to the Project Management Body of Knowledge: PMBOK Guide, $6^{\text {th }}$ Edition, Project Management Institute.

[19] Reed G. E., 2006, Leadership and Systems Thinking, "Defense Acquisition, Technology and Logistics", 35(May-June), pp. 10-13.

[20] Roser T., 2014, Aligning the Co-Creation Project Portfolio with Company Strategy, "Strategy \& Leadership", 42(1), pp. 30-36.

[21] Sharma M., Smith P., 2002, Developing Personal Responsibility and Leadership Traits in All Your Employees: Part 2 - Optimally Shaping and Harmonizing Focus, Will and Capability, "Management Decision", 40, pp. 814-822.

[22] Solansky S. T., 2008, Leadership Style and Team Processes in Self-Managed Teams, "Journal of Leadership \& Organizational Studies", 14(4), pp. 332-341.

[23] Zander L., Mockaitis A. I., Butler C. L., 2012, Leading global teams, “Journal of World Business", 47(4), pp. 592-603. 